\title{
INDONESIA SEBAGAI TRENDSETTER MODERATISME DI ASEAN (Membangun Relasi Akademik antara Islam dan Multikulturalisme)
}

\author{
Winarto Eka Wahyudi \\ Universitas Islam Lamongan \\ Email: ekawahyudi1926@unisla.ac.id
}

\section{Article History:}

Received: 09-02-2019

Revised: 20-02-2019

Accepted: 05-03-2019

\begin{abstract}
Indonesia is the largest Muslim majority country in the world. So it makes perfect sense if Islam in Indonesia becomes the centre of civilization on the international scene. However, this achievement is not easy because it demands moral responsibility that Islam indeed shows its moderate and tolerant face. Why is this important? Because the entire Islamic region in the Middle East country, only shows Islam in front of conflict and war. So, the claim that the future of Islamic civilization in the world is in the hands of Indonesia is not a mere figment. For this reason, Indonesian Islam must be able to maintain and simultaneously make efforts to support the preservation of Islam that is friendly to all elements of the nation. For this reason, in this paper, the author describes how strategies so that Islam can become a value base to give birth to attitudes of moderates in the frame of Multicultural Islamic education.
\end{abstract}

Keyword: Indonesian Islam, Moderatism, Multicultural, Islamic Education

\section{Pendahuluan}

Semenjak kian melesatnya arus teknologi yang berdampak pada semakin mudahnya akses informasi, ternyata tidak hanya melahirkan efek positif. Bahkan, sumber konflik dewasa ini terwujud melalui media sosial. Dengan mendaku pada nilai-nilai demokrasi, melalui media online siapapun seakan menjadi generasi "orang pintar baru" yang merasa mampu untuk mengomentari segala macam hal walau tanpa dilandasi basis keilmuan yang mapan. Ironisnya, komentar-komentar yang jamak dipertontonkan cenderung merangsek pada sentiment-sentimen suku, ras dan agama. Tentu saja, hal ini jika dibiarkan akan membahayakan masa depan bangsa Indonesia sebagai Negara multikultural yang dikenal mampu menjaga dan merawat keharmonisan sosial di tengah heteregonitas pendnduduknya.

Konflik sosial yang mengambil bentuknya melalui media sosial ini, menegaskan akan resistensi konflik yang semakin multidimensional di Indonesia, telah banyak kajian dan hasil penelitian baik dalam upaya pemetaan faktor-faktor konflik itu maupun upaya pencarian resolusinya. Kini sudah saatnya upaya serupa diarahkan kepada pencarian potensi kedamaian yang mungkin dapat diimplementasikan dalam mengatasi berbagai konflik serta memperkuat bangunan kesatuan bangsa. Seperti halnya sumber-sumber konflik yang ditemukan berasal dari berbagai faktor ideologi, sosial, ekonomi, politik, 
teknologi dan sebagainya, maka demikian pula sumber-sumber kedamaian dapat digali dari berbagai aspek tersebut.

Dalam hal ini misalnya, potensi lembaga pendidikan sebagai institusi pengembangan sumber daya manusia dengan sub-kulturnya sekaligus, menjadi potensi yang perlu dilirik, untuk selanjutnya dikembangkan untuk melahirkan budaya damai dengan mengambil agama islam sebagai segmentasi kajiannya. Kenapa dengan entitas agama islam? Alasan yang paling mendasar adalah, karena dewasa ini, Islam dianggap sebagai agama yang paling tidak toleran akibat dari tindakan-tindakan terorisme dan radikalisme yang direpresentasikan oleh kelompok-kelompok islam tertentu. Tentu saja, menjadi sangat relevan jika kajian-kajian keislaman yang berada di lembaga pendidikan, perlu dilakukan reformulasi melalui desain kajiannya yang mengapresiasi segala macam perbedaan-perbedaan. Sehingga, akan menghasilkan out put pemikiran yang lebih terbuka, inklusif dan demokratis sebagai bagian dari upaya menjaga masa depan multikkulturalisme di Indonesia.

\section{Islam dan Multikulturalisme: Tinjauan Relasi Akademik}

Islam sebagai sebuah agama, secara substansial masih tetap istiqāmah dalam mempertahankan tradisi kedamaian, keseimbangan, dan keharmonisan. Jika ditelisik dalam doktrin ajarannya, islam mempunyai konsep persaudaraan yang pernah diintrodusir oleh seorang ulama par-exellent melalui konsep trilogy ukhuwah-nya, yaitu yang dikenal dengan prinsip ukhūwah Islāmīyah (persaudaraan sesama umat islam), ukhāwah wathanīyah (persaudaraan kebangsaan), dan ukhūwah basyarīyah (persaudaraan kemanusiaan) dalam upaya memperkuat bangunan Negara Kesatuan Republik Indonesia (NKRI) sekaligus ikut serta membangun tata kehidupan global yang damai. $^{1}$

Karakteristik Islam yang ditampilkan oleh para ulama yang menjadi simbol utama islam pasca kenabian, jamak mengajarkannya adalah penanaman dan pengembangan nilai-nilai infitah (inklusif), tawassuth (moderat), musāwah (persamaan), dan tawāzun (seimbang). Sebagai sebuah ajaran nilai, islam sejatinya mmapu tampil sebagai agen pembudayaan nilai-nilai universal, norma, sekaligus pesan-pesan keagamaan yang sarat dengan harmoni, kerukunan, persatuan dan kedamaian. Bahkan para sarjanawab menilai, islam -melalaui lembaga pendidikannya- mempunyai peran yang cukup signifikan dalam melestarikan budaya lokal, termasuk memelihara nilai-nilai multikultural yang telah menjadi fakta sosial yang tak bisa ditolak. ${ }^{2}$

Dalam konteks pendidikan Islam multikultural, sebagaimana yang menjadi tema dalam pembahasan ini, multikultural adalah sikap menerima kemajemukan ekspresi budaya manusia dalam memahami pesan utama agama, terlepas dari rincian anutannya. Basis utamanya dieksplorasi dengan berlandaskan pada ajaran Islam, sebab dimensi Islam menjadi dasar pembeda sekaligus titik tekan dari konstruksi pendidikan ini. Dalam Islam sebenarnya sudah dijelaskan tentang penciptaan manusia yang terdiri dari

\footnotetext{
${ }^{1}$ Masdar Hilmy. Islam, Politik dan Demokrasi, (Surabaya: Imtiyaz, 2014), 89.

${ }^{2}$ Nunu Ahmad an-Nahidil, "Pesantren dan Dinamika Pesan Damai" Edukasi: Jurnal Penelitian Agama dan Keagamaan, Vol.4 No.3 (2006), 18.
} 
berbagai macam perbedaan, baik itu warna kulit (ras, suku dan sebagainya) maupun bahasa. Seperti yang termuat dalam Q.S al-Rum: 22

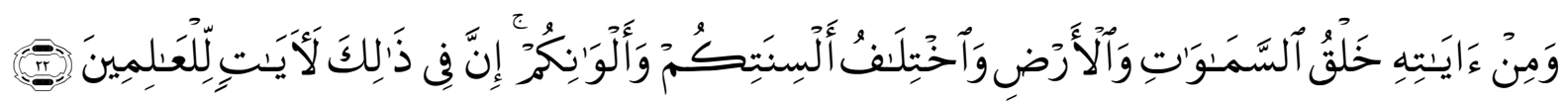

"Dan di antara tanda-tanda kekuasaan-Nya ialah menciptakan langit dan bumi dan berlain-lainan bahasamu dan warna kulitmu. Sesungguhnya pada yang demikan itu benar-benar terdapat tanda-tanda bagi orang-orang yang Mengetahui"

Lebih lanjut, bahkan dijelaskan dengan lebih tegas dalam Q.S. al-Mumtahanah: 8 yang menyebutkan bahwa manusia dianjurkan untuk berbuat baik dan adil kepada semua manusia walaupun memilikiperbedaan yang paling asasi, yakni agama :

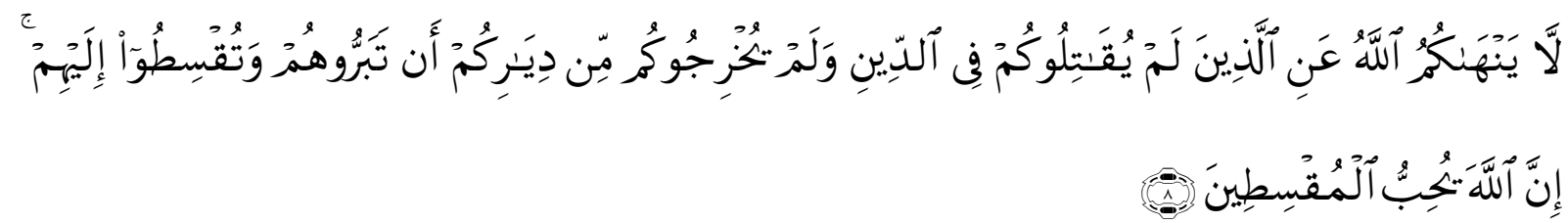

"Allah tidak melarang kamu untuk berbuat baik dan berlaku adil terhadap orangorang yang tiada memerangimu Karena agama dan tidak (pula) mengusir kamu dari negerimu. Sesungguhnya Allah menyukai orang-orang yang berlaku adil"

Memahami makna dari kandungan ayat tersebut di atas, bahwa sesungguhnya dalam ajaran Islam sangat menghargai adanya perbedaan, karena memang perbedaan adalah suatu hal yang niscaya. Oleh karena itu, islam harus dipelajari, dikaji, diperbincangkan dan diperdebatkan secara akademik, namun dalam konteks hubungan sosial, islam justru harus menjadi elemen perekat yang mampu melunturkan berbagai perdebatan dan perbedaan. Pada posisi ini, islam menempatkan nilai-nilai universal sebagai medan prioritas. Karena, jika tidak malah akan terjeban pada monopoli kebenaran yang mengarah pada pertikaian tak berkesudahan.

Selanjunya, Robert John Ackermann misalnya, pernah menyatakan bahwa kritik memang tidak membuat agama layu, tetapi agama yang tidak dapat melancarkan kritik berarti sudah mati. ${ }^{3}$ Dengan istilah lain, bahwa agama pada satu sisi memang jamak menjadi sumber kritik, terutama kritik sosial yang abadi, tetapi umumnya agama tidak sama dengan kritik sosial. Karena, agama juga mampu menjadi sumber integrasi dalam masyarakat. Pada konsekuensi terakhir ini, maka perspektif nilai-nilai multikulturalisme seperti keadilan, toleransi dan demokasi menjadi bagian tak terpisahkan dalam pengkajian islam. ${ }^{4}$

\footnotetext{
${ }^{3}$ Robert John Ackermann, Religion as Critique, (New York: The University of Massachusetts Press Post Office Box, 1985), 5.

${ }^{4}$ Agama sebagai sumber integrasi merupakan fenomena yang universal yang telah ada bersama dengan adanya manusia, maka tentu tidak menutup kemungkinan fenomena ini dipahami berbeda oleh mereka yang berasal dari lingkup wilayah dan periode waktu yang berlainan, seperti yang ditawarkan oleh Walter H. Capps bahwa agama (religion) sebagai "a set of bilief, syimbol and practices, which is based on the idea of the sacred, and which unites believers into a socio-religions community".(seperangkat kepercayaan, perlambang dan praktek, yang di dasarkan atas ide tentang yang sakral, dan mengintegrasikan mereka yang percaya ke dalam komunitas
} 
Karena, jika islam dipahami secara sempit tanpa melihat melalui perspektif yang luas, malah akan menjadi sumber konflik, tetapi kalau agama dipahami secara substantive-integratif dan universal, dalam kata lain dengan mempertimbangkan entitas kultur lain, bahkan akan melahirkan peradaban. Dengan demikian agama yang dipelajari, diperbincangkan, dan diamalkan oleh penganutnya secara sungguh-sungguh, mampu melahirkan peradaban yang damai dan harmonis, karena agama mempunyai peranan yang urgen dalam memberi arah dan arti bagi kehidupan manusia.

Sehingga, pada posisi ini islam sebagai obyek kajian tidak hanya berfungsi sebagai wacana spiritual, namun secara sekaligus juga mampu menjadi pedoman sosial dan budaya yang bisa menghadirkan rasa aman dan damai. Jika tidak demikian, maka bukan hal yang mustahil "islam" akan menampilkan sosoknya yang seram dan menakutkan. Agama bisa meletupkan konflik dan pertikaian antar elemen masyarakat, ketika diinterpretasi sesuai dengan kepentingan sepihak umat atau kelompok agama, tanpa memandang multikulturalis sosial. Interpretasi yang subjektif ini, pada gilirannya dapat menjadi legitimasi para pemeluk agama untuk membunuh dan mengorbankan perang atas nama Tuhan dan kitab suci. Konflik-konflik semacam ini, bisa terjadi sepanjang masih terjadi garis pemisah antara agama dan kebudayaan. ${ }^{5}$

\section{Strategi Pengembangan Pendidikan Islam Berbasis Multikulturalisme}

Sudah sewajarnya, jika pola pendidikan islam di Indonesia memperhatikan corak dan karakter kebangsaan sebagai sebuah Negara yang multikultur. Kesadaran tersebut, harus di awali melalui lembaga pendidikan yang menjadi basis penanaman nilai-nilai. Hal ini penting, mengingat jika islam dipahami dari perspektif yang sempit dan tidak komplek, akan melahirkan kekakauan cara berfikir yang pada gilirannya melahirkan konflik yang disebabkan oleh sentimen-sentimen ideologi. Kasus konflik yang berkepanjangan sebagaimana diperlihatkan di Iraq, Suriah, Yaman, Sudan dan beberapa Negara Timur Tengah yang lain, bahkan di beberapa wilayah Indonesia, merupakan bukti konkrit bahwa ketidaksepahaman ideologi,walauapun dalam satu agama, jika tidak kelola dengan baik, akan melahirkan orok bernama peperangan. ${ }^{6}$

sosio-religius). Selengkapnya dalam Walter H. Capps, Religious Studies: The Making of a Disipline, (Minneapolis: Fortress Press, 1995), 203.

${ }^{5}$ Konflik-konflik yang dimaksudkan adalah konflik-konflik berdarah yang terjadi di India antara umat Islam dan Hindu, pertempuran antara Yahudi Israel dan Kaum Muslim Palestina, pertempuran antara Kristen Katolik dan Protestan di Irlandia Utara, demikian juga pertikaian yang memuncak di Lebanon antara milisi Syi'ah dan Druz, pembasmian etnis Bosnia- Herzegovina oleh etnis Serbia, pertentangan masyarakat Persia di Iran dan masyarakat Arab di Saudi Arabia di zaman Ayatullah Komeini, penindasan suku Aborringin oleh warga kulit putih Autralia, Senketa yang terjadi antara pemerintah Filipina dan kaum muslimin Moro, pertentangan cultural yang terjadi antara suku Kreol dan budaya Perancis di Amerika Latin, sekedar contoh rawan dan riskannya "garis" yang memisahkan agama yang satu dengan agama yang lain, kebudayaan yang satu dengan kebudayaan yang lain. Lihat, M. Nasir Tamara, (Ed.) Agama Dan Dialog Antar peradaban, (Jakarta: Penerbit Paramadina, 1996), xix.

${ }^{6}$ Isu seksi yang jamak digunaka sebagai penyulut konflik antar madzhab pemikiran adalah isu sunni-syiah. Dilatarbelakangi oleh kepentingan ekonomi dan politik, isu agama menjadi andalan paling efektik guna memobilisasi konflik agar sesama saudara saling baku pukul. Realitas ini sebagaimana yang terekam pada kasus penggulingan Bashar Al-Asad di Suriah, konfllik Sunni-Syiah di Iraq, Serangan milliter Saudi Arabia di Yaman, kasus dan di Sampang, Madura juga tak luput dari konflik yang dipicu melalui isu ini. Belum lagi, terkait kasus penyerangan Jama'ah Ahmadiyah . 
Untuk itu, perlu menginisiasi strategi guna meminimalisir konflik di satu sisi, sekaligus menanamkan kesadaran multikultural yang apresiatif terhadap segala macam perbedaan pada sisi yang lain. Di lain makna, pendidikan islam harus di desain menggunakan pendekatan-pendekatan serta instrument yang mampu melahirkan sikap yang toleran dan terbuka. Beberapa hal yang patut untuk digagas antara lain:

\section{Formulasi Kompetensi}

Kompetensi pendidikan multikultural yang mampu melahirkan sikap mmoderatisme, dapat dikategorikan kedalam tiga macam kompetensi. Pertama, kompetensi attitude. Dalam sikap, peserta didik diorientasikan untuk memiliki kesadaran dan kepekaan kultural yang pada gilirannya mampu memupuk jiwa toleransi kultural, penghargaan terhadap identitas kultural, serta sikap responsive terhadap budaya, dan yang paling puncak dalam kompetensi ini adalah kesanggupannya untuk menghindari serta meresolusi konflik di tengah masyarakat. Karena moderatisme merupakan unsur nilai yang harus dimanisfestasikakan ke dalam sikap, maka kompetensi ini dalam perpsketif pengembangan pendidikan menjadi kompetensi primer yang wajib terpenuhi sekaligus terukur pencapaiannya.

Kedua, kompetensi cognitive. Aspek kognitif, peserta didik diarahkan tidak hanya memiliki memiliki pengetahuan, namun secara sekaligus mempunyai pemahaman terhadap bahasa dan budaya orang lain, memiliki kemampuan menganalisis dan menerjemahkan prilaku kultural masing-masing orang, serta pengetahuan tentang kesadaran melalui perspektif kultural.

Ketiga, kompetensi instructional. Dalam aspek instruksional ini, peserta didik mampu memperbaiki distorsi, stereotip, dan kesalahpahaman tentang kelompok etnik yang dipandang negative dan peyoratif oleh kelompok tertentu, serta memiliki kemampuan dalam melakukan komunikasi lintas budaya sekaligus menguasai pola komunikasi interpersonal sehingga mampu memberikan pemahaman-pemahaman mendasar tentang pentingnya persatuan yang dibingkai dalam solidaritas kultural. ${ }^{7}$

\section{Desain Materi}

Materi pendidikan islam yang mempunyai orientasi sikap moderatisme, bukan merupakan materi yang berdiri sendiri, dengan kata lain memiliki perspektif yang beragam. Dalam konteks ini, kajian islam harus diarahhkan pada pemahaman yang multi perpesktif, sehingga pandangan dan pemahaman tentang islam menjadi lebih kaya dan luas. Gagasan mempelajari islam dengan materi lintas madzhab, pembelajaran sejarah peradaban islam, tasawuf dan berbagai macam piranti keilmuan islam lain, akan melahirkan infrastruktur berfikir yang kokoh dan tak mudah goyah dengan beragam perbedaan pendapat. Strategi pembelajaran semacam ini, merupakan implementasi materi pendidikan multikultural yang dapat melahirkan nilai-nilai yang dapat mempengaruhi pola fikir, pola sikap, dan pola tindakannya lebih moderat dan terbuka terhadap perbedaan.

7 Abdullah Ali, Pendidikan Islam Multikultural di Pesantren, Telaah terhadap Kurikulum Pondok Pesantren Modern Islam as-Salam Surakarta (Yogyakarta, Pustaka Pelajar, 2011), 56. 
Gary Burnett sebagaimana dikutip Abdullah Aly, mengkategorikan kurikulum berbasis multikultural pada content oriented program, di mana materi pendidikan multikultural ditambahkan pada kurikulum yang ada dalam bentuk isu-isu dan konsep multikultural. ${ }^{8}$ Demikian pula James A. Banks dalam tulisannya Multikulturalism's Five Dimensions menyatakan bahwa kurikulum pendidikan multikultural yang berorientasi pada materi dapat dilakukan dengan mengintegrasikan materi multikultural ke dalam kurikulum. ${ }^{9}$

\section{Pola Academic Experience}

Proses merupakan salah satu komponen inti kurikulum pendidikan multikultural, karena itu fokus pendidikan multikultural di samping pada materi, hal yang sangat penting adalah proses. Menurut Mark K. Smith, ada tiga karakteristik kurikulum yang berorientasi pada proses, yaitu;

a) Menjadikan kelas sebagai ruang interaksi atau komunikasi interpersona baik antara pendidik dengan peserta didik, maupun antar peserta didik, yang tidak hanya bersifat edukatif, tapi juga inklusif dan demokratis. Dalam konteks ini, peserta didik diarahkan dan dibimbing untuk memahami bagaimana interaksi yang baik, tidak hanya dikelas namun juga di luar kelas. Melalui pemahaman-pemahaman yang terbuka terhadpa segala perbedaan serta memanifestasikan seruan al-Quran sebagaimana yang dijabarkan dalam surat al-Rum : 20 dan al-Mumtahanah: 8 sebagaimana yang dijelaskan pada bagian sebelumnya dari pembahasan ini.

b) Memposisikan peserta didik sebagai subjek pembelajaran dengan pendekatan learning process. ${ }^{10}$ Pendekatan ini berorientasi pada proses, dengan maksud utama untuk melahirkan masyarakat pembelajar (learning society). Karena, pada dasarnya peserta didik adalah generasi yang tetap akan membaur dan bersosialisasi di tengah masyarakat. untuk itu, pemahaman-pemahaman tentang pentingnya sikap moderartisme, keterbukaan, saling mengapresiasi perbedaan, merupakan kunci dalam proses pembelajaran.

Selanjutnya, dalam konteks pengembangan islam dan multikulturalisme dalalm bingai pendidikan, penulis merujuk pada karya James A. Banks yang mengidentifikasi konstruk pendidikan yang dikategorisasikan menjadi lima dimensi. Melalui kelima dimensi inilah, penulis mencoba untuk "merelasikan" antara islam dan multikulturalisme menjadi kesatuan akademik yang, di satu sisi berpotensi mampu menghasilkan output pendidikan yang dapat melahirkan pemahaman-pemahaman yang moderat. Dan sisi yang lain, merupakan teoritisasi proses pendidikan islam yang selama ini diterapkan oleh pesantren dan terbukti mampu melahirkan manusia-manusia yang terbuka terhadap perbedaan. Adapun kelima dimensi yang dimaksud adalah sebagai berikut: ${ }^{11}$

${ }^{8}$ Ibid., 132.

James A. Banks, Multikulturalism's Five Dimension, dalam http://www.leaner.org/chanel/whorkshop/socialstudies/pdf/sesion3/3.Multikulturalism.pdf, 1. Diakses pada tanggal 23 Agustus 2017

10 Abdullah Ali, Pendidikan Islam Multikultural, 138.

${ }^{11}$ James A. Bank, Multicultural Education: Historical Development, Dimension and Practice, American Educational Research Association, 5 
a) Dimensi integrasi isi/ materi (content integration). Dimensi dapat digunakan oleh pendidik untuk memberikan keterangan dengan 'poin kunci' pembelajaran dengan merefleksi materi yang berbeda-beda. Secara khusus, para guru menggabungkan kandungan materi pembelajaran ke dalam kurikulum dengan beberapa cara pandang yang beragam. Salah satu pendekatan umum adalah mengakui kontribusinya, yaitu guru-guru bekerja ke dalam kurikulum mereka dengan membatasi fakta tentang semangat kepahlawanan dari berbagai kelompok. Di samping itu, rancangan pembelajaran dan unit pembelajarannya tidak dirubah. Dengan beberapa pendekatan, guru menambah beberapa unit atau topik secara khusus yang berkaitan dengan materi multikultural. Untuk itu, pada konteks materi ini, peserta didik perlu difasilitasi untuk mengembangkan nilai-nilai dan komitmen yang dibutuhkan dalam rangka mengembangakan kemampuan mengakui dan menghargai kemajemukan dalam masyarakat. di dalam pesatren, sejatinya implementasi dimensi ini sudah lama ada. Melalui metode musyawarah dan bahsul masail, bahkan santri diajari untuk berbeda pendapat serta dengan sadar dan sukarela untuk menerima pendapat orang lain yang memiliki kadar kebenaran masing-masing. Bahkan, yang lebih canggih lagi, bahwa sebagaimana dikatakan oleh Zahro, bahsul masail di lingkungan pesantren merupakan media akademik yang digunakan guna memecahkan permasalahan sosial di tengah masyarakat. persoalan sosial tersebut, tentu tak hanya berhubugan dengan ibadah, namun juga mencakup permasalahan maudhu'iyyah (kasuistik), waqi'iyah (aktual), dan qonuniyah (hukum/perundangan) yang belum ada kepastian hukumnya dalam al-Quran dan Hiadits secara jelas. ${ }^{12}$

b) Dimensi konstruksi pengetahuan (knowledge construction). Suatu dimensi dimana para guru membantu siswa untuk memahami beberapa perspektif dan merumuskan kesimpulan yang dipengaruhi oleh disiplin pengetahuan yang mereka miliki. Dimensi ini juga berhubungan dengan pemahaman para pelajar terhadap perubahan pengetahuan yang ada pada diri mereka sendiri. Dalam konteks ini, filsafat eksistensialisme sangat relevan dijadikan sebagai landasan pengembangan karena bersentuhan dengan pendidikan, karena dalam eksistensialisme dinyatakan bahwa realitas yang sesungguhnya adalah yang berwujud (reality as existence). Dengan kata lain, kebenaran merupakan pilihan, dan nilai bersumber dari individu. ${ }^{13}$ Oleh karena itu, peran dalam hal ini sebagai fasilitator yang membantu peserta didik dalam menemukan jati dirinya, guru memperlakukan peserta didik secara individual, menghargai keragaman yang melekat pada masing-masing peserta didik, baik aspek rasional maupun emosionalnya.

c) Dimensi pengurangan prasangka (prejudice ruduction). Dalam konteks dimensi ini, harus melakukan banyak usaha untuk membantu siswa dalam mengembangkan perilaku positif tentang difersitas sosial. Sebagai contoh, ketika anak-anak masuk

${ }^{12}$ Ahmad Zahro, Lajnah Bahtsul Masa'il 1926-1999: Tradisi Intelektual NU, (Yogyakarta, LKiS, 2004), 17.

${ }^{13}$ George R. Knight, Issues and Alternatives in Educational Philosophy (Michigan: Andrews University Press, 1992), 69. 
sekolah dengan perilaku negatif dan memiliki kesalahpahaman terhadap ras atau etnik yang berbeda dan kelompok etnik lainnya melalui stigma-stigma negative yang muncul, maka fungsi edukatif dapat membantu siswa mengembangkan perilaku intergroup yang lebih positif, penyediaan kondisi yang mapan dan pasti. Dua kondisi yang dimaksud adalah bahan pembelajaran yang memiliki citra yang positif tentang perbedaan kelompok dan menggunakan bahan pembelajaran tersebut secara konsisten dan terus-menerus. Penelitian menunjukkan bahwa para pelajar yang datang ke sekolah dengan banyak stereotipe, cenderung berperilaku negatif dan banyak melakukan kesalahpahaman terhadap kelompok etnik dan ras dari luar kelompoknya. Secara lebih teknis, model pembelajaran cooperative laerning juga dapat membantu para pelajar untuk mengembangkan perilaku dan persepsi terhadap ras agar lebih positif. Jenis strategi dan bahan dapat menghasilkan pilihan para pelajar untuk lebih bersahabat dengan ras luar, etnik dan kelompok budaya lain. karena, mau tidak mau, melalui strategi ini selain menuntut pelajar untuk membaur dengan etnis lain, secara terus menerus, maka akan membentuk kebiasaan yang pada gilirannya menumbuhkan kesadaran kultural. Pada posisi inilah, pengurangan prasangka-prasangka negative dapat dieliminir.

d) Dimensi pendidikan yang sama/adil (equitable pedagogy). Dimensi ini memperhatikan cara-cara dalam mengubah fasilitas pembelajaran sehingga mempermudah pencapaian hasil belajar pada sejumlah siswa dari berbagai kelompok. Strategi dan aktivitas belajar yang dapat digunakan sebagai upaya memperlakukan pendidikan secara adil, antara lain dengan bentuk kerjasama (cooperative learning), dan bukan dengan cara-cara yang kompetitif (competition learning). Dimensi ini juga menyangkut pendidikan yang dirancang untuk membentuk lingkungan sekolah, menjadi banyak jenis kelompok, termasuk kelompok etnik, wanita, dan para pelajar dengan kebutuhan khusus yang akan memberikan pengalaman pendidikan persamaan hak dan persamaan memperoleh kesempatan belajar.

e) Dimensi pemberdayaan budaya sekolah dan struktur sosial (empowering school culture and social structure). Dimensi ini penting dalam memperdayakan budaya siswa yang dibawa ke sekolah yang berasal dari kelompok yang berbeda. Di samping itu, dapat digunakan untuk menyusun struktur sosial (sekolah) yang memanfaatkan potensi budaya siswa yang beranekaragam sebagai karakteristik struktur sekolah setempat, misalnya berkaitan dengan praktik kelompok, iklim sosial, latihanlatihan, partisipasi ekstra kurikuler dan penghargaan staf dalam merespon berbagai perbedaan yang ada di sekolah.

Lebih lanjut, pendekatan yang bisa dipakai dalam proses pembelajaran untuk menghasilkan sikap moderat adalah pendekatan kajian kelompok tunggal (Single Group Studies) dan pendekatan perspektif ganda (Multiple Perspektives Approach). Pendidikan multikultural di Indonesia pada umumnya memakai pendekatan kajian kelompok tunggal. Pendekatan ini dirancang untuk membantu siswa dalam mempelajari pandangan-pandangan kelompok tertentu secara lebih mendalam. Oleh karena itu, harus tersedia data-data tentang sejarah kelompok itu, kebiasaan, pakaian, rumah, makanan, 
agama yang dianut, dan tradisi lainnya. Data tentang kontribusi kelompok itu terhadap perkembangan musik, sastra, ilmu pengetahuan, politik dan lain-lain harus dihadapkan pada siswa. Pendekatan ini terfokus pada isu-isu yang sarat dengan nilai-nilai kelompok yang sedang dikaji. Pendekatan ini, dalam kategori Ahmad Munjid, diistilahkan sebagai pendekatan multireligious. ${ }^{14}$

Sedangkan pendekatan perspektif ganda (Multiple Perspectives Approach) adalah pendekatan yang terfokus pada isu tunggal yang dibahas dari berbagai perspektif kelompok-kelompok yang berbeda. Pada umumnya, guru-guru memiliki berbagai perspektif dalam pembelajarannya. Dalam kaitan ini, pembelajaran menggunakan pendekatan perspektif ganda, dengan alasan pendekatan itu nampak lebih efektif. Kunci dalam pendekatan ini adalah adanya semangat dialogis untuk mencari titik temu diantara beragam perspektif yang ada. Sehingga, terciptanya rekonsilisasi dan kohesi sosial tidak mustahil terwujud. Munjid, mengkategorikan perpsketif ini melalui pendekatan interreligious. ${ }^{15}$

Pendekatan perspektif ganda membantu siswa untuk menyadari bahwa suatu peristiwa umum sering diinterpretasikan secara berbeda oleh orang lain, dimana interpretasinya sering didasarkan atas nilai-nilai kelompok yang mereka ikuti. Solusi yang dianggap baik oleh suatu kelompok (karena solusi itu sesuai dengan nilai-nilainya), sering tidak dianggap baik oleh kelompok lainnya karena tidak cocok dengan nilai yang diikutinya.

Bahan pelajaran dan aktivitas belajar yang kuat aspek afektifnya tentang kehidupan bersama dalam perbedaan kultur terbukti efektif untuk mengembangkan perspektif yang fleksibel. Siswa yang memiliki rasa empati yang besar memungkinkan dia untuk menaruh rasa hormat terhadap perbedaan cara pandang. Tentu saja hal itu akan mampu mengurangi prasangka buruk terhadap kelompok lain. Membaca buku sastra multietnik dapat mengurangi stereotipe negatif tentang budaya orang lain. Pendekatan perspektif ganda mengandung dua sasaran yaitu meningkatkan empati dan menurunkan prasangka. Empati terhadap kultur yang berbeda merupakan prasyarat bagi upaya menurunkan prasangka.

\section{Relevansi Kajian Multikultural di Lembanga Pendidikan Indonesia}

Pada dasarnya, pembelajaran berbasis multikultural didasarkan pada gagasan filosofis tentang kebebasan, keadilan, kesederajatan dan perlindungan terhadap hak-hak manusia. Hakekat pendidikan multikultural pada konteks filofis ini, mengorientasikan terhadap peserta didik untuk belajar secara aktif menuju kesamaan struktur tak hanya di lembaga sekolah, namun juga di tengah masyarakat. Pendidikan multikultural, dalam konteks ini bukan sebuah kebijakan yang mengarah pada pelembagaan pendidikan dan pengajaran inklusif yang dimaksudkan dalam rangka melakukan propaganda pluralisme, namun lebih pada pembentukan mental dan pemahaman yang mengarah pada sikap budaya yang egaliter dan apresiatif terhadap kemajemukan.

${ }^{14}$ Afifurrahman Sya'rani, Mengkaji Agama-Agama secara Interreligius, Jurnal Kelas, dalam crcs.ugm.ac.id, diakses pada 12 September 2017.

15 Ibid., 
Dalam tataran regulatif, pemerintah sebenarnya sudah menjadikan isu multikultural dalam kebijakannya yang dituangkan dalam Undang-Undang Sisdiknas No 20 Tahun 2003, sehingga dalam konteks ini sesungguhnya pendidikan multikultural tak lain merupakan penerjemahan dari UU tersebut, yang mengamanatkan bahwa pendidikan nasional harus diselenggarakan secara demokratis dan berkeadilan serta tidak diskriminatif dengan menjunjung tinggi hak asasi manusia, nilai keagamaan, nilai kultural, dan kemajemukan bangsa. ${ }^{16}$

Selain itu, pembelajaran berbasis multikultural dalam hal ini merupakan usaha untuk memberdayakan siswa dalam rangka mengembangkan rasa hormat kepada orang yang memiliki diferensiasi kultural, selain itu pembelajaran multikultural juga diorientasikan kepada pemberian kesempatan untuk bekerja bersama dengan orang atau kelompok orang yang berbeda etnis atau ras secara langsung. Pendidikan dengan mengedapankan dan mempertimbangkan realitas multikultural, juga membantu siswa untuk mengakui fakta dari pandangan-pandangan budaya yang beragam, membantu siswa dalam mengembangkan kebanggaan terhadap warisan budaya mereka, menyadarkan siswa bahwa konflik nilai primordial sering menjadi penyebab konflik antar kelompok masyarakat. ${ }^{17}$

Pendidikan multikultural dalam hal ini, diselenggarakan sebagai upaya membentuk dan mengembangkan kemampuan siswa dalam memandang kehidupan dari berbagai perspektif budaya yang berbeda dengan budaya yang mereka miliki, sekaligus bersikap positif terhadap perbedaan budaya, ras, dan etnis. ${ }^{18}$ Adapun tujuan pengajaran dengan berbasis pada keniscayaan multikultural dapat diidentifikasi sebagai berikut:

1. Untuk memfungsikan peranan sekolah dalam memandang keberadaan siswa yang beranekaragam;

2. Untuk membantu siswa dalam membangun perlakuan yang positif terhadap perbedaan kultural, ras, etnik, kelompok keagamaan;

3. Memberikan ketahanan siswa dengan cara mengajar mereka dalam mengambil keputusan dan keterampilan sosialnya;

4. Untuk membantu peserta didik dalam membangun ketergantungan lintas budaya dan memberi gambaran positif kepada mereka mengenai perbedaan kelompok. ${ }^{19}$

Pada tataran yang lebih tinggi, sejatinya pembelajaran dengan mengedepankan nilai-nilai multikultural banyak memiliki urgensinya yang penting dalam konteks untuk menciptakan kondisi sosial yang lebih baik. Pada tataran ini, pendidikan multikultural memiliki keutamannya sendiri, antara lain:

16 Undang-Undang Sistem Pendidikan Nasional No 20 Tahun 2003 BAB III tentang Prinsip Penyelenggaraan Pendidikan Pasal 4 ayat 1.

${ }^{17}$ T.V Savage \& Armstrong, D.G, Effective Teaching in Elementary Social Studies (Ohio: Prentice Hall, 1996), 17.

${ }^{18}$ P.J Farris \& S.M Cooper, Elementary Social Studies: a Whole language Approach (Iowa: Brown \& Benchmark Publishers, 1994), 27.

${ }^{19}$ James .A. Banks,. "Multikultural Educatian: Historical Development, Dimentions and Practrice" In Review of Research in Education, vol. 19, edited by L. Darling- Hammond. (Washington, D.C.: American Educational Research Association, 1993), 28, dan D.J Skeel,. Elementary Social Studies: Challenge for Tomarrow"s World (New York: Harcourt Brace College Publishers, 1995), 53. 
1. Memberikan terobosan baru pembelajaran yang mampu meningkatkan empati dan mengurangi prasangka siswa atau mahasiswa sehingga tercipta manusia (warga negara) antarbudaya yang mampu menyelesaikan konflik dengan tanpa kekerasan (nonviolent);

2. Menerapkan pendekatan dan strategi pembelajaran yang potensial dalam mengedepankan proses interaksi sosial dan memiliki kandungan afeksi yang kuat;

3. Model pembelajaran multikultural membantu guru dalam mengelola proses pembelajaran menjadi lebih efisien dan efektif, terutama memberikan kemampuan peserta didik dalam membangun kolaboratif dan memiliki komitmen nilai yang tinggi dalam kehidupan masyarakat yang serba majemuk;

4. Memberikan kontribusi bagi bangsa Indonesia dalam penyelesaian dan mengelola konflik yang ernuansa SARA yang timbul di masyarakat dengan cara meningkatkan empati dan mengurangi prasangka. Kondisi keberagaman masyarakat dan budaya, secara positif menggambarkan kekayaan potensi sebuah masyarakat yang bertipe pluralis, namun secara negatif orang merasa tidak nyaman karena tidak saling mengenal budaya orang lain. Setiap etnik atau ras cenderung mempunyai semangat dan ideologi yang etnosentris, yang menyatakan bahwa kelompoknya lebih superior daripada kelompok etnik atau ras lain. ${ }^{20}$

Selanjutnya, kenyataan bahwa tidak semua siswa antara satu dengan yang lain tidak saling mengenal dan memahami identitas budaya orang lain, berpotensi mendorong meningkatnya prasangka terhadap orang lain, berupa sikap antipati yang didasarkan pada kesalahan generalisasi yang diekspresikan sebagai perasaan. Prasangka negative tersebut, terkadang juga diarahkan kepada sebuah kelompok secara keseluruhan, atau kepada seseorang hanya karena itu adalah anggota kelompok tertentu. Dengan demikian, prasangka memiliki potensi dalam mengambinghitamkan orang lain melalui stereotype yang bernuansa peyoratif, dan diskriminasi sehingga berdampak pada terciptanya jarak sosial. 21

Untuk mengatasi fenomena ini, sesungguhnya pemerintah telah memberikan rambu melalui Peraturan Menteri Pendidikan yang salah satu poin pentingnya dalam kelompok mata pelajaran Kewarganegaraan dan Kepribadian untuk Kelompok mata pelajaran kewarganegaraan dan kepribadian dimaksudkan untuk peningkatan kesadaran dan wawasan peserta didik akan status, hak, dan kewajibannya dalam kehidupan bermasyarakat, berbangsa, dan bernegara, serta peningkatan kualitas dirinya sebagai manusia. Kesadaran dan wawasan termasuk wawasan kebangsaan, jiwa dan patriotisme bela negara, penghargaan terhadap hak-hak asasi manusia, kemajemukan bangsa, pelestarian lingkungan hidup, kesetaraan gender, demokrasi, tanggung jawab sosial, ketaatan pada hukum, ketaatan membayar pajak, dan sikap serta perilaku anti korupsi, kolusi, dan nepotisme. ${ }^{22}$

${ }^{20}$ Alo Liliweri, Prasangka \& Konflik: Komunikasi Lintas Budaya Masyarakat Multikultural. (Yogyakarta: LKiS, 2005), 34.

${ }^{21}$ C. Bennett, \& E Spalding, "Teaching the Social Studies: Multiple Approaches for Multiple Perspectives" In Theory and Reseach in Social Education, 1992), 263-292.

${ }^{22}$ Peraturan Menteri Pendidikan Nasional No 22 Tahun 2006 tentang Standart Isi untuk Satuan Pendidikan Dasar dan Menengah pada BAB II pada bahasan Kerangka Dasar dan Struktur Kurikulum, 2. 
Melalui pembelajaran multikultural, subyek belajar dapat mencapai kesuksesan dalam mengurangi prasangka dan diskriminasi. Dengan kata lain, sekolah mempunyai variabel yang seimbang dalam memperlakukan antar kelompok rasial dan etnis yang memiliki pengalaman dan hak yang sama dalam proses pendidikan. Pelajar mampu mengembangkan keterampilannya dalam memutuskan sesuatu secara bijak. Konsekuensi positif yang ditimbulkan adalah mereka lebih banyak menjadi subyek dari pada menjadi obyek dalam suatu kurikulum. Mereka menjadi individu yang mampu mengatur dirinya sendiri dan merefleksi kehidupan untuk bertindak secara aktif.

Di sisi lain, mereka juga bisa membuat keputusan dan melakukan sesuatu yang berhubungan dengan konsep, pokok-pokok masalah yang mereka pelajari. Mereka akan mampu secara mandiri mengembangkan visi sosial yang lebih baik dan memperoleh ilmu pengetahuan dan keterampilan serta mengkonstruksinya dengan sistematis dan empatis.

Kemudian, dalam kaitannya dengan penyusunan kurikulum pendidikan multikultural, ada beberapa hal yang harus diperhatikan:23

Pertama, penyusunan kurikulum harus didasarkan kepada keimanan pada Tuhan Yang Maha Esa, norma-noram, atau nilai-nilai absolute yang diambil dari agama-agama besar di dunia dan hubungan integral antara Tuhan, manusia, dan alam.

Kedua, karena ilmu pengetahuan dari Tuhan, manusia tidak dapat disebut sebagai pembuat ilmu pengetahuan. Namun, karena manusia dapat dengan mudahnya menemukan aspek-aspek yang terkandung di dunia ini, maka nilai-nilai kemanusiaan dapat dijadikan sebagai inspirasi untuk menyeleksi, menginvestigasi, dan menikmati adanya sebuah kebenaran.

Ketiga, peserta didik diharuskan mengetahui hierarki antara ilmu pengetahuan dan sumber nilai. Ilmu pengetahuan diperoleh melalui sebuah pengalaman yang harus tunduk terhadap pengetahuan rasional, dan pengetahuan rasional harus tunduk terhadap norma-norma agama yang berasal dari Tuhan.

Keempat, keimanan dan nilai-nilai harus diakui sebagai dasar kebudayaan manusia. Oleh sebab itu, keduanya tidak boleh dipisahkan dalam proses belajar mengajar. Ilmu pengetahuan tidak harus ditunjukkan sebagai sesuatu yang bertentangan dengan pandangan agama. Dengan demikian, dalam pendidikan hal itu harus digunakan untuk mendorong nilai-nilai yang baik.

Kelima, peserta didik harus didorong untuk mengetahui prinsi-prinsip unity and diversity dan menyadari adanya dasar-dasar keamanan yang menembus dunia biologis dan psikis. Ini sebuah refleksi terhadap kesatuan prinsip-prinsip pencapaian dunia. Dunia adalah sebuah sistem yang mempersatukan dan terdapat suatu hubungan integral diantara bagian-bagian yang berbeda-beda.

Selanjutnya, untuk merumuskan tujuan melalui kurikulum tentang strateggi pengajaran berbasis multikultural, Suniti mengutip pendapat John Dewey mengemukakan bahwa pendidikan multikultural seharusnya memfokuskan pada kurikulum yang berkaitan langusng dengan pemberian pengalaman sehari-hari siswa. Dengan mempersiapkan peserta didik untuk aktivitas kehidupan tertentu, pendidikan

${ }^{23}$ Syamsul Mu'arif, Pendidikan Pluralisme di Indonesia, (Jogjakarta: Rake Sarasin, 2000), 102. 
memungkinkan peserta didik untuk mampu memecahkan masalah-masalah mereka hadapi secara teratur, terutama terkait diversitas sosial yang menjadi fenomena empiris peserta didik. Dengan demikian pendidikan multikultural dapat dikembangkan unutk diarahkan pada beberapa kompetensi dasar, diantaranya: ${ }^{24}$

1. Mengembangkan kompetensi akademik standar dasar (standar and basic academic skills) dalam tujuan pendidikan secara umum dan pengajaran secara khusus tentang nilai persatuan dan kesatuan, demokrasi, keadilan, kebebasan, persamaan derajat atau saling menghargai dalam beraneka jenis keragaman.

2. Mengembangkan kompetensi sosial agar dapat menumbuhkan pemahaman yang lebih baik ( $a$ better understanding) tentang latar belakang budaya dan agama sendiri dan juga budaya dan agama lain dalam masyarakat.

3. Mengembangkan kompetensi akademik untuk menganalisis dan membuat keputusan yang cerdas (intelligent decisions) tentang isu-isu dan masalah keseharian (real-life problems) melalui sebuah proses demokratis atau penyelidikan dialogis (dialogical inquiry).

4. Membantu mengkonseptualisasi dan mengaspirasikan konstruksi masyarakat yang lebih baik, demokratis, dan egaliter tanpa ada diskriminasi, penindasan, dan pelanggaran terhadap nilai-nilai yang universal.

Melalui deskripsi singkat tentang model hubungan antara kurikulum dan pengajaran, serta urgensitas nilai-nilai multicultural dalam dunia pendidikan, maka penulis cenderung lebih memilih model siklus (the cyclical model) sebagai model yang tepat terkait hubungan antara kurikulum dengan pengajaran berbasis multikultural. Rasionalisasi sangat sederhana, karena dalam pandangan penulis model ini menggambarkan hubungan timbal balik antara kurikulum sebagai learning experience di satu sisi, dan pengajaran sebagai aktifitas interaksional antara pendidik dan peserta didik di sisi yang lain. Keduanya dapat mempengaruhi antar satu dengan yang lain tanpa harus menegasikan eksistensi masing-masing, antara mana yang mendominasi dan aspek apa yang harus diposisikan sebagai subordinat, sebagaimana model konsentris (concentric model).

Selain itu, pada pengajaran berbasis multicultural merupakan manifestasi dari UU Sisdiknas No 20 Tahun 2003 tentang tatalaksana penyelenggaraan Pendidikan, serta Peraturan Menteri Pendidikan Nasional No 22 Tahun 2006 tentang stardar isi bagi sekolah dasar dan menengah yang mengedepankan hak asasi manusia dan kemajemukan bangsa sebagai subject matter dalam aspek pembelajaran. Kesalingterkaitan ini, meniscayakan model siklus menjaid pilihan yang tepat dalam mengimplementasikan pendidikan multicultural secara nasional. Karena secara regulatif, isu-isu multikultural telah tercover dalam kurikulum nasional.

Hal inilah yang diinginkan oleh James A Bank yang mengatakan bahwa pendidikan multikultural dapat terlaksana dengan sukses manakala dilakukan perubahan kelembagaan, termasuk perubahan dalam kurikulum; materi ajar; pengajaran dan gaya

${ }^{24}$ Suniti, "Kurikulum Berbasis Multikultural”, Edueksos, Vol III No 2, Juli 2014, 38. 
pengajaran, yang meliputi; sikap, persepsi, dan perilaku guru dan administrator..$^{25}$ Sehingga dalam konteks ini, bahwa segala yang ditentukan dalam kurikulum akan menjadi dasar pertimbangan dalam proses pelaksanaan pengajaran. Namun juga sebaliknya, dalam proses pengajaran dapat dijadikan sebagai feedback untuk mereformulasi kurikulum agar sesuai dengan karakter kebudayaan bangsa, terutama Indonesia.

\section{Kesimpulan}

Banyak para ahli yang mneyatakan bahwa Indonesia merupakan gudangnya ilmu sosial. Namun ironisnya, kajian-kajian tentang ilmu sosial sendiri sangat minim dilakukan oleh para peneliti. Tentu, hal ini menjadi sangat tidak masuk akal mengingat Negara ini menyimpang jutaan potensi sosial berupa keragaman suku, budaya, bahasa dan agama. Keragaman tersebut di satu sisi mampu menjadi modalitas sosial guna menciptakan kondisi masyarakat yang harmonis dan egaliter. Namun, di sisi lain, potensi tersebut jika tidak dikelola dengan baik, akan melahirkan disintegrasi bangsa yang sangat mengerikan. Tragedi-tragedi kemanusiaan, yang menjadikan diferensiasi sosial sebagai latarbelakang konflik sebagaimana yang terjadi di ambon, poso, sampang, tolikara, aceh, dan lain sebagainya, turut mencoreng wajah Indonesia yang dikenal dunia sebagai Negara yang aman dan mempunyai tingkat toleransi terhadap keberagaman yang tinggi.

Ironisnya, konflik-konflik etnis dan agama tersebut, walau dilatarbelakangi oleh kepentingan ekonomi dan politik, jamak mendaku pada sentiment suku dan agama. Dari sinilah konflik menjelma menjadi perang saudara antar elemen bangsa. Maka, menjadi sangat relevan jika realitas sejarah ini, harus segera dipotong bibit-bibitnya melalui lembaga pendidikan. Karena, melalui pendidikanlah manusia dididik dan diajarkan bagaimana menjadi warga Negara yang baik, sekaligus menjadi umat beragama yang beradab. Dengan menjadikan pendidikan sebagai basis perubahan, maka bukan hal yang mustahil Indonesia mampu menjadi satu-satunya Negara di dunia yang mampu melakukan persenyawaan kultural antara islam dan kebudayaan sehingga menjadi trendsetter peradaban islam dunia. Karena, Negara-negara mayoritas islam di Timur Tengah, terkesan gagal dalam mengkontektualisasikan islam di tengah kekayaan lokal.

\section{Daftar Pustaka}

Masdar Hilmy. Islam, Politik dan Demokrasi, Surabaya: Imtiyaz, 2014.

Nunu Ahmad an-Nahidil, "Pesantren dan Dinamika Pesan Damai” dalam Edukasi, Jurnal Penelitian Agama dan Keagamaan, Vol.4 No.3. Jakarta: Puslitbang Pendidikan Agama dan Keagamaan, Badan Litbang dan Diklat Departemen Agama RI, 2006.

${ }^{25}$ There is general agreement among most scholars and researchers that, for multicultural education to be implemented successfully, institutional changes must be made, including changes in the curriculum; the teaching materials; teaching and learning styles; the attitudes, perceptions, and behaviors of teachers and administrators: and the goals, norms, and culture of the school, selengkapnya lacak dalam James A. Bank, Multikultural Educatian: Historical Development, Dimentions and Practrice" In Review of Research in Education, vol. 19, 4. 
Robert John Ackermann, Religion as Critique, New York: The University of Massachusetts Press Post Office Box, 1985.

Walter H. Capps, Religious Studies: The Making of a Disipline, Minneapolis: Fortress Press, 1995.

M. Nasir Tamara, (Ed.) Agama Dan Dialog Antar peradaban, Jakarta: Penerbit Paramadina, 1996

Abdullah Ali, Pendidikan Islam Multikultural di Pesantren, Telaah terhadap Kurikulum Pondok Pesantren Modern Islam as-Salam Surakarta. Yogyakarta, Pustaka Pelajar, 2011.

James A. Bank, Multicultural Education: Historical Development, Dimension and Practice, American Educational Research Association

Ahmad Zahro, Lajnah Bahtsul Masa'il 1926-1999: Tradisi Intelektual NU, Yogyakarta, LKiS, 2004.

George R. Knight, Issues and Alternatives in Educational Philosophy (Michigan: Andrews University Press, 1992.

Undang-Undang Sistem Pendidikan Nasional No 20 Tahun 2003 BAB III tentang Prinsip Penyelenggaraan Pendidikan Pasal 4 ayat 1.

T.V Savage \& Armstrong, D.G, Effective Teaching in Elementary Social Studies. Ohio: Prentice Hall, 1996.

P.J Farris \& S.M Cooper, Elementary Social Studies: a Whole language Approach. Iowa: Brown \& Benchmark Publishers, 1994.

James .A. Banks,. "Multikultural Educatian: Historical Development, Dimentions and Practrice" In Review of Research in Education, vol. 19, edited by L. DarlingHammond. (Washington, D.C.: American Educational Research Association, 1993.

D.J Skeel,. Elementary Social Studies: Challenge for Tomarrow"s World. New York: Harcourt Brace College Publishers, 1995.

Alo Liliweri, Prasangka \& Konflik: Komunikasi Lintas Budaya Masyarakat Multikultural. Yogyakarta: LKiS, 2005.

C. Bennett, \& E Spalding, "Teaching the Social Studies: Multiple Approaches for Multiple Perspectives" In Theory and Reseach in Social Education, 1992.

Peraturan Menteri Pendidikan Nasional No 22 Tahun 2006 tentang Standart Isi untuk Satuan Pendidikan Dasar dan Menengah pada BAB II pada bahasan Kerangka Dasar dan Struktur Kurikulum.

Syamsul Mu'arif, Pendidikan Pluralisme di Indonesia, Jogjakarta: Rake Sarasin, 2000.

Suniti, “Kurikulum Berbasis Multikultural”, Edueksos, Vol III No 2, Juli 2014, 38.

James A. Bank, Multikultural Educatian: Historical Development, Dimentions and Practrice" In Review of Research in Education, vol. 19, 4. 